\title{
JÁNOS KORNAI AND GENERAL EQUILIBRIUM THEORY*
}

\author{
Mehrdad VAHABI
}

This paper explores the evolution of Kornai's thought on general equilibrium theory (GET) and his position on mainstream economics. Three moments in this evolution will be highlighted, starting by his rejection of GET and advocating disequilibrium in Anti-Equilibrium (1971). While Kornai does not treat the "equilibrium paradigm" as irrelevant, he suggests an alternative paradigm, namely economic systems theory that he further develops in the 1980s as "system paradigm". Economics of Shortage (1980) marks a second phase in which Kornai distinguishes Walrasian equilibrium from normal state or Marshallian equilibrium. In this phase, he supports Marshallian equilibrium rather than disequilibrium. Finally, By Force of Thought (2006) is a critical self-appraisal in which Kornai considers Anti-Equilibrium as a "failure" and acknowledges GET as a benchmark of an ideal competitive market. He now advocates a Walrasian equilibrium as an abstract reference model, but refuses to consider this model as a description of reality. In this sense, he rejects the New Classical economics. Paradoxically, however, his original heterodox concept of "soft budget constraint", irreconcilable with standard microeconomics, has been integrated into new microeconomics as an optimal intertemporal strategy of a maximizing agent in the absence of credible commitments. It will be argued that Kornai's so-called failure is rather related to his half-in, half-out mainstream position, while his institutionalist system paradigm is still a heterodox research project of the future.

Keywords: disequilibrium, economic systems theory, General Equilibrium Theory, Marshallian and Walrasian equilibrium, new microeconomics, normal state, system paradigm

JEL classification indices: B3, D5, E1, E7, P2, P5

* I would like to offer my gratitude to Editor-in-Chief Peter Mihalyi as well as Wladimir Andreff, Bernard Chavance, Bertrand Crettez, Geoffrey Hodgson, Sylvie Lupton, and Tarik Tazdait for their inspiring and insightful remarks on an earlier version of this paper. Obviously, all remaining errors are mine.

Mehrdad Vahabi, Professor of Economics at the University of Paris 13 (Centre d'Economie de l’Université Paris-Nord, CEPN). E-mail: mehrdad.vahabi@wanadoo.fr 
"Anti-Equilibrium is not merely an item on my list of publications. It was the most ambitious enterprise of my career as a researcher. I had undertaken something bigger and more difficult than what I was able to accomplish. I am aware of that, but it still does not make its failures easy to come to terms with".

(Kornai 2006, p. 197).

\section{INTRODUCTION}

János Kornai has largely contributed to the introduction of general equilibrium theory (GET) in Hungary and the Eastern bloc in general. While his book, AntiEquilibrium (1971a), provided a detailed critical review of GET, it also presented the main idea, method, and assumptions of the theory to a whole generation of Marxist and non-Marxist economists in the Soviet bloc. As a fervent advocate of the mathematical school, Kornai admired the mathematical rigor of Arrow, Debreu, Hahn, Hurwicz, McKenzie, and other GET theorists and welcomed this line of work as part of a new field of research in economics, for which he coined the expression "economic systems theory" (Kornai 1971a: 1-2). However, he questioned the validity of GET as a "real-science" theory and argued that it was only an "intellectual experiment" (ibid.: 11-12) that needed a "revolution" to come to terms with a scientific explanation of economic realities. "A synthesis of the careful attempts to improve the equilibrium theory may turn the 'reform' into a 'revolution', into discarding and transcending the orthodox theory" (ibid.: 367).

Kornai's position on GET in the early seventies radically changed throughout time. After the initial rejection (Anti-Equilibrium), he gradually came to revise and accept the main message of the theory. He first accepted GET as a benchmark for an efficient perfect competitive market in the late 1970s and during the 1980s. The Economics of Shortage (1980) represents this first revision. Summing up his reflections on this major project of his life in 2006, he revised his position for a second time and acknowledged his error in calling for a "revolution" and accepted Hahn's (1973) criticism of Anti-Equilibrium with regard to the philosophy of science as well as the possibility to improve the theory through successive "reforms". Kornai regretted his critical standpoint in many respects and while believed it had been worth publishing Anti-Equilibrium, he deemed the whole adventure a "failure" (Kornai 2006:197).

Interestingly enough, despite his long "adventurous" journey in exploring GET, he incessantly regarded this theory as part of economic systems theory and not as the core of "pure political economy" (Walras 1874/1965) or standard microeconomics. This leads us to raise a fundamental question about Kornai's 
initial project: was it about the shortcomings of GET or the promotion of an alternative theory of economic systems that he later named "system paradigm" (Kornai 2016)? And how should the "failure" be assessed: was it a failure of AntiEquilibrium or a failure of systems theory?

In reviewing Kornai's position on GET, we will first study the intellectual background of the early 1970s (Section 1), and then successively discuss three moments in the evolution of his thought concerning equilibrium, namely Anti-Equilibrium (1971) (Section 2), Economics of Shortage (1980) (Section 3), and By Force of Thought (2006) (Section 4). Section 5 will explore Kornai's position on new microeconomics with regard to equilibrium. We will finally conclude by examining the causes of Kornai's so-called "failure".

\section{THE INTRODUCTION OF GET IN THE EASTERN BLOC}

The center of economic thought was transferred from British Cambridge to American Cambridge after World War 2. The Cambridge Capital theory controversies (Cohen - Harcourt 2003) in the 1960s between Samuelson and Solow at the MIT on the one hand, and Joan Robinson and Piero Sraffa at the University of Cambridge on the other, mark this important turning point. The mathematical school dominated the economic discipline, despite the serious unanswered challenges by the post-Keynesian school regarding the notion of capital and the reswitching issue. The formulation of GET accentuated the tension between post-Keynesians and the proponents of the Walrasian general equilibrium or the so-called "Neoclassical” school. This confrontation was already intense at the University of Cambridge between two contending groups, one led by Joan Robinson and Nicholas Kaldor, and the other by Frank Hahn in the early 1970s.

Kaldor's lecture on "The Irrelevance of Equilibrium Economics" claims unequivocally that "the powerful attraction of the habits of thought engendered by 'equilibrium economics' has become a major obstacle to the development of economics as a science - meaning by the term 'science' a body of theorems based on assumptions that are empirically derived (from observations) and which embody hypotheses that are capable of verification both in regard to the assumptions and the predictions (1972: 1237). Kaldor reiterates Kornai's distinction between an "intellectual experiment" and a "real-science theory" (ibid.: 1238) and describes GET as one of "continual degress, not progress" from the former to the latter. ${ }^{1}$

For an informative paper on commonalities and divergences between Kaldor and Kornai, see Mihalyi (2017). 
What was Kornai's position in this controversy? More recently, Kornai described his position in the following terms: "Nowadays, I like to characterize myself as having one foot in and one foot out of the mainstream" (Kornai 2006: 195). Although Anti-Equilibrium is rather a direct challenge to mainstream economics, Kornai is not wrong to say that even in this work, he had one foot in the mainstream: "I consider myself a mathematical economist; thus my critical remarks come not from 'outside' but from 'inside' the circle. These remarks, therefore, may be regarded in many cases as self-criticism as well as criticism. It is my conviction that the further progress of economic theory will depend, if not exclusively, at least significantly, on the advances made in the field of mathematical economics. It is in this area that I hope my work can make a contribution” (Kornai 1971a: 4). This message has not gone unnoticed by Hahn when he reviewed Kornai's book: "I have found it hard to understand what it is that Kornai wants to be done. For he is not against formal reasoning; indeed he laments the lack of new Von Neumanns” (Hahn 1973: 330).

According to Kornai, his relationship with both contending groups at the University of Cambridge was a major reason for Richard Stone offering him a position at that university: "There was tension mounting there between two groups, one of mathematical economists, headed intellectually by Frank Hahn, and the other opponents of such methods, centering around Joan Robinson and my fellow countryman Nicholas (later Lord) Kaldor. His probing of opinion so far suggested to him that both sides would be pleased to see me given a chair, a development that might even help to ease the tension. He offered the professorship not on his own initiative, but on behalf of his colleagues" (Kornai 2006: 219). While Kornai declined the offer, he tried to entertain a regular, interactive intellectual contact between the Eastern and the Western economists, particularly with mainstream economics. Maintaining his Hungarian Academy of Sciences affiliation and coming from a socialist system gave solid credentials to Kornai to be heard by economists all over the socialist camp. ${ }^{2}$

At the time, the post-Keynesian economists were known to the Soviet economists. Although they were not regarded as "bourgeois economists", Paul Samuelson and other neoclassical economists were often labeled as such. "Up to the present, the GE [general equilibrium] theory has been criticized mainly by Marxist economists engaged in the history of theory and in the critique of bourgeois economics,

2 Kornai's influence in the Chinese economic reform since the Bashan Conference (September 16-23, 1985) was partially related to this point which is stressed by Kornai and his wife Zsuzsa Dániel themselves after their trip to China (1986: 302): "We think that French or American authors, lacking personal experience, can hardly understand and interpret the Chinese events of the last decade ... With Hungarians, empathy comes much more naturally.” 
and not by those whose interest is concentrated on the socialist economy and on the constructive development of economic systems theory” (Kornai 1971b: 316). Kornai pleaded for a change of attitude towards the neoclassical economics and neoclassical economists. He emphatically insisted on the political and ideological indifference of GET: "in my opinion, the GE theory is politically indifferent and sterile. Its strictly axiomatic form does not contain any unequivocal political interpretation. The theory's axioms and basic assumptions may be good or bad - but they are politically indifferent ... the GE theory admits of a variety of political interpretations. It may constitute the ideology of a strictly centralized special 'market socialism' (Lange). Models closely related to the GE theory may serve to justify the hypothesis of a strictly centralized socialist economy planned by computers, as described by some Soviet authors. But the same model may, according to another interpretation, serve as the ideology of a completely decentralized and liberal capitalist 'free-market' economy (see e.g. Röpke’s works). The GE theory must not necessarily be termed anti-socialist, notwithstanding the role played by anti-socialist concepts in its coming into being and development. From the purely political point of view, its axioms and ways of posing questions could be acceptable both to Marxists and non-Marxists” (Kornai 1971b: 315). During the Cold War, Kornai was not the only scholar who sought a "common language" between capitalist and socialist currents. Before Kornai, Claude Lévi-Strauss (1954: 650) regarded game theory as that common language: "This new economics simultaneously contributes to two grand currents of thought that have shared economic science until now. On the one hand, pure economics that identifies homo oeconomicus as a perfectly rational individual; on the other hand, the sociological and historical economics that has been founded by Karl Marx and which is principally devoted to the dialectics of combat. Yet the two aspects are both present in the theory of von Neuman. Consequently, for the first time, a common language is provided for bourgeois or capitalist economics, as well as Marxist one.” GET and game theory were both used by Marxist and liberal economists.

The political and ideological sterility thesis was a strong argument for entertaining a regular collegial relationship with the Western neoclassical economists. It should be recalled that the same argument saved the Soviet mathematical school. Novozhilov, Kantorovitch, and other proponents of the Soviet marginalist school could continue their research thanks to this political sterility thesis. Kornai himself scrupulously clung to this thesis and systematically detoured economic topics with strong political implications in all his works before the post-socialist transition. For example, in the preface to The Economics of Shortage (1980: 13), Kornai explicitly excluded a discussion of the political system and ideological principles of communist regimes as well as their international relationships within the CMEA. However, he did tackle these questions after the collapse of the So- 
viet system (Kornai 1992). He applied the same method in conducting common research programs with neoclassical economists.

In addition to the political sterility thesis, Kornai maintained that the knowledge about GET had a universal cultural value: "No economist can be called educated and well-versed in his own branch of science who does not know thoroughly the general equilibrium theory and does not make it clear to himself, what his own relation is to this theory" (Kornai 1979a: 196). This cultural aspect could have a strong echo at a time when Soviets were accusing the Chinese "Cultural Revolution" as a campaign against all universal cultural values. Finally, in promoting GET, Kornai also extolled certain personal qualities of its architects: "Although he [Arrow] is not in the frontline of political fights, he does not keep away from public affairs. He was among those who protested against US intervention in Vietnam and against racial discrimination” (Kornai 1979a: 201).

Undoubtedly, GET could not be introduced in Hungary or any other socialist economy without being severely criticized. But Kornai did not wish to close the door to GET and end the discussion by labeling it a "bourgeois ideology": "It is not for political reasons that the GE theory should be rejected but because it cannot be properly used. It constitutes an economic systems theory that is not workable" (Kornai 1971b: 316). His book was a prolegomenon for the revolt against GET, but as Kovács (1991: 51) aptly remarked, "Ironically, since the publication of his Anti-Equilibrium in 1971, whole generations of Hungarian economists have been introduced to the general equilibrium model through its critique. Kornai's polemical work had a paradoxical impact on the evolution of reform economics. Strangely enough, this was the first book in the history of Hungarian postwar political economy whose author wanted, based on an extensive knowledge of economics in the West, to open a dialogue with the adherents of the latter. Unfortunately, however, he could not manage to pierce the 'splendid isolation' of reform economics.” Clearly speaking, Kornai rendered a significant service to mainstream economics: it was through his work that Hungarian economists became familiar with GET.

\section{ANTI-EQUILIBRIUM: SYSTEM PARADIGM VERSUS EQUILIBRIUM PARADIGM}

To periodize different phases of Kornai's standpoint on GET, I will associate each period with one of his major works without excluding his other works. Kornai's initial position on the subject is presented in Anti-Equilibrium. There are surely other papers during the period 1971-1979 that reflect this first phase of Kornai's position (see, for example, Kornai 1971b, c, 1972). 
In the economic literature, GET is always considered as the core of standard microeconomics. Walras introduced his GET in the Elements of Pure Economics (1874) devoted to price theory under a "hypothetical state of absolute competition" (concurrence absolue). Arrow, Debreu, and the advocates of the neoclassical synthesis interpreted GET as microeconomics and the Hicks IS/LM model as macroeconomics or the income theory. Kornai's taxonomy is somehow completely different. He does not classify GET as a branch of micro- or macroeconomics, but as part of a new branch that he termed "economic systems theory". "Economic systems theory is but one branch, one domain of economics, and does not embrace economic science in its entirety. Another branch of economics is macroeconomics ..., it treats the economy as a whole. A further branch is microeconomics which analyses ... some part of the economy. Economic systems theory is, however, separate from both, wishing to deal, as has been pointed out above, with the relationship between the whole and the part" (Kornai 1971b: 302).

But what is economic systems theory about? Kornai cites Leontief's interbranch input-output model as an illustration. While this model captures the material structure of the economy or the production-technical relations between production and consumption, the focus of economic systems theory should be on the way the control of material processes is taking place, what information serves this purpose, what are the characteristics of the decision processes of economic organizations, and in sum how the decision-information-motivation structure functions. ${ }^{3}$ The Leontief model describes the "body" of the economy, whereas economic systems theory is centered on the "soul", the "brain", and the "nervous system”. Kornai's biological depiction of economic activity emphasizes the organic nature of the system. ${ }^{4}$ But what is the "soul", the "brain", and the "nervous system" of the economy?

According to Kornai, this includes, first of all, the "organizations and institutions [that] are functioning within the system beside the basic units of production and consumption, i.e. the firm and the household" (ibid.: 302-303). Institutions and organizations are the "soul" of economic systems. The next is the DecisionInformation-Motivation structure which is the equivalent of the "brain" (decisionmaking center), and finally coordination mechanisms (market, bureaucratic, etc.) provide the "nervous system". In Kornai's view, while a vast literature has been published in micro- and macroeconomics, "in economic systems theory, only

3 Comparing economic systems, Duffy - Neuberger (1976) describe the economic processes in terms of Decision-Information-Motivation (DIM) structure.

$4 \quad$ It is not the only place where Kornai compares economy with biology. Kornai (1983b) explores the similarities between the medical sciences and economics. 
very few major works have been published so far. ... The GE [General Equilibrium] theory can be rightfully classified as belonging to the domain of economic systems theory" (Kornai 1971b: 303-304). This statement is somehow awkward, not only because the inceptors of GET consider it as the core of microeconomics, but also because this model does not satisfy most of Kornai's criteria.

In fact, how can an axiomatic representation of economy include institutions and organizations? The firm is nothing but a black box in GET and the institutions are reduced to two fictional entities: (1) Walras' crieur des prix that replaces all relationships among decentralized agents; (2) the Compensation Chamber replacing money. As Kornai $(1984,1992)$ correctly noted, there is no "coordination" mechanism in GET; there is only an "allocation" mechanism since the model is exempt of all institutions and organizations coordinating decentralized agents. The economic systems theory in the case of GET is thus reduced to the possibility of the emergence of an order or an equilibrium. But Kornai argues that while the axiomatic reasoning is valid as an "intellectual experiment", it is not a "real-science theory" because of four fundamental assumptions of the model that are in conflict with the reality: (1) The stationary character of the model that precludes change; (2) Optimality or maximizing assumption for describing the behavior of firms and consumers that reduces the complexity of their behaviors; (3) The convexity assumption that excludes economies of scale; and finally (4) uncertainty and diversity of quantity versus price signals that are not captured in the model (Kornai 1971a: 19-23; 1971b: 307-313).

The critique of optimality is also stressed by Herbert Simon (1979: 508) in his Nobel laureate speech, in which Kornai is cited for showing the dichotomy between supply-driven and demand-driven management. The rejection of the convexity assumption is particularly supported by Kaldor's (1972) major paper on the irrelevance of equilibrium. In his Nobel laureate speech, Arrow refers to the issue of non-price signals in both Leijonhufvud (1968, especially Chapter 2) and Kornai (1971a), but he then adds: "Nevertheless, while the criticisms are, in my judgment, not without some validity, they have not given rise to a genuine alternative model of detailed resource allocation" (1974: 254).

In fact, the conceptors of GET have never denied that their assumptions were often unverifiable or contradictory with realities. They regard this "unrealism" as part of axiomatic or formal modeling, and acknowledge that "The issue is not at all whether Kornai is correct when he points at important problems: it is how they should be tackled" (Hahn 1973: 329). Illustrating his point, Hahn underlines the treatment of sequence economies as well as of stochastic equilibria in the later works of General Equilibrium theorists by relaxing some of the initial axioms of the model while retaining others. He then asks, "Why does Kornai object to a sequence of 'reforms' which a good many people are now engaged in 
and why does he think it a good strategy to introduce them all simultaneously?” (ibid.: 328). Kornai calls for a revolution since he assumes that the introduction of realist assumptions will lead to disequilibrium rather than equilibrium. Kornai acknowledges two possible interpretations of GET, one "normative", the other "descriptive". However, he thinks that both interpretations are unjustified: according to Kornai, GET is neither a valid "normative" model nor a "descriptive one". "What is needed is a criticism of both interpretations which cannot be separated from each other. The descriptive interpretation is the primary one. ... No normative theory can be taken seriously which cannot be carried into practice" (Kornai 1971b: 305).

From a normative viewpoint, "disequilibrium is preferable to equilibrium" (Kornai 1971b: 314) and from a descriptive viewpoint, the typical state is not equilibrium, but constant deviation from the latter, namely excess supply (surplus) or excess demand (shortage). The former is named "pressure", the latter "suction". ${ }^{5}$ The third part of Anti-Equilibrium, as well as Kornai (1971c), are devoted to the investigation of these two types of constant deviations from equilibrium. Suction is linked to a "shortage" economy in which sellers are dominant over buyers. In contrast to suction, pressure is associated with a "surplus" economy where buyers dominate sellers on the market. According to Kornai (1971c: 35), "while equilibrium is more favorable than suction, slight pressure is more advantageous than equilibrium.” Generally speaking, pressure is preferable to suction, since more progress takes place in a pressure than in a suction economy (ibid.: 15). But what is the cause of suction or pressure? Are they engendered by specific property relationships or institutional structures such as socialism or capitalism?

Kornai's (1971a, b, c, 1972) answer to this question is negative. "Suction conditions can exist in both socialist and nonsocialist countries. Suction often accompanies war in capitalist economies. It has also appeared in several nonsocialist developing Asian and African countries. This indicates that suction is not exclusive to socialist ownership relations, but rather arises due to certain economic situations or policies” (Kornai 1971c: 18). In Kornai’s opinion, Hungary began the transition from a suction (shortage) to a pressure (surplus) economy in

5 “Pressure” and "suction” are Kornai’s terminological innovation. Hahn (1973: 328) harshly criticized this type of innovation and preferred the use of "excess supply" for "pressure" and "excess demand” for "suction”. Kornai (1971c: 34) was against this conflation: “Although they are obviously related, the two concept pairs 'pressure-suction" and 'excess supply-excess demand” are not synonymous.” Kornai (1980: 89-90) acknowledged the lack of success for his terminological innovations, and he conceded that "I have to say that the two names were not accepted by economists or in general speech and I abandoned them in later writings, turning to the expressions 'buyers' market' and 'sellers' market,' which had earlier become current among economists” (2006: 189). 
the aftermath of the New Economic Mechanism (January 1, 1968). This transition was notably successful in the food industry, the light industry, and certain parts of engineering related to consumption branches as well as in export industries. By contrast, strong suction persisted in the building industry. Kornai revised this position by the end of the 1970s and clearly advocated an institutionalist approach in Economics of Shortage (1980). ${ }^{6}$

To sum up Kornai's critical assessment of GET in the early 1970s, it can be said that he opposed "disequilibrium" to "equilibrium". If economic systems theory should have completed Leontief's model by studying the "soul", the "brain", and the "nervous" system of the economy, then how could disequilibrium provide a better understanding of economic systems theory? It seems to me that instead of opposing a more comprehensive systems theory to GET, Kornai took another path, a path which was determined by GET. This path was an investigation of disequilibrium. Contrarily to Kaldor, Kornai did not consider equilibrium as irrelevant. He gave the pride of place to this concept by searching for its "negation" or disequilibrium. Other issues related to the economic systems theory, namely system paradigm, were neglected. The Socialist System (1992) provides a theoretical framework comprising the "soul", the "brain" and the "nervous" system of the economy. Interpreting the change of system, Kornai (1992), set out to clarify what a "great" system means. He summed up three major characteristics of any economic system: (1) political structure and related dominant political ideology; (2) property relationships; (3) coordination mechanisms (the relative weight of market, bureaucratic, ethical, or other types of coordination mechanisms). These three principal constituents of an economic system depict the hierarchy of the causal chain: the first bloc determines the second, and that in turn conditions the third (Kornai 1992: 360-365). In his recent paper on the system paradigm, Kornai (2016: 549) acknowledges that what he calls a "great system" is related to the neo-Marxist concept of social formation.

Wrong or right, this is another line of reasoning than that of GET since it is about the relationship between the parts and the whole of an economic system and not only microeconomics; it embraces institutional structures and coordination (and not allocation) mechanism. ${ }^{7}$ This systems theory brings back politics into economics and searches for the political economy of communism or any other system. And, last but not least, its multi-disciplinary character allows us

$6 \quad$ For a detailed investigation about this change of position in Kornai from economic policy to institutional factors, particularly behavioral regularities, see Vahabi (1993).

7 Allocation mechanism is about the way scarce resources are allocated. Its focus is on the relationship between humans and resources rather than the relationship between humans (among individuals and organizations). The latter is captured by coordination mechanism. 
to study the issue of system change. This line of reasoning is also different from the one followed by Kornai in opposing GET in 1971 since while it emphatically looks into the emergence, persistence, and demise of an "order", it is not imprisoned by disequilibrium versus equilibrium. Political sterility was an ally for introducing GET as well as for proposing partial economic reforms in the ex-socialist systems, but it was of no avail for the task of founding an alternative road to economic systems theory. How could the critical position of Kornai then be characterized in Anti-Equilibrium?

I would say that it was anti-neoclassical. But what do I mean by the neoclassical school? I adopt Hahn's (1984: 1-2) definition of this term: "I have frequently, and especially in my university, been classified as a neoclassical economist. ... There are three elements in my thinking which may justify it: (1) I am a reductionist in that I attempt to locate explanations in the actions of individual agents. (2) In theorising about the agent I look for some axioms of rationality. (3) I hold that some notion of equilibrium is required and that the study of equilibrium states is useful.” Returning to Kornai (1971), all three elements are rejected.

First, as a fervent advocate of economic systems theory, Kornai does not support reductionism or methodological individualism. In fact, he does not even acknowledge GET as a branch of microeconomics.

Second, Kornai is against rationality and optimality assumptions. He explicitly rejects the idea that individual consumers define their choices in accordance with the transitivity criterion: "As for me, I doubt if individual behavior is 'rational' in the neoclassical interpretation of the word. In the series of individual actions inconsistence, and a frequent violation of the transitivity principle and of some other postulates of 'rational behavior' are observable. Social decisions seem to be even less consistent. It often happens that a decision-making body today prefers A to $\mathrm{B}$, tomorrow $\mathrm{B}$ to $\mathrm{C}$, and after-tomorrow $\mathrm{C}$ to $\mathrm{A}$. In observing the series of consecutive and comparable decisions we can see vacillation - in a better case experimentation, and in a worse one simply inconsistence” (Kornai 1979a: 200).

Third, in Anti-Equilibrium, Kornai does not consider that the study of equilibrium is useful. Indeed, he strongly argues that the notion of disequilibrium is much more useful.

8 Although Hahn's definition of the term is particularly relevant in this context to classify Kornai's position with regard to GET, it is perhaps not the most accurate definition. Among others, Gary Becker (1976: 5) captures the underpinning tenets of neoclassical approach as practiced today when he describes it as "the combined assumptions of maximizing behavior, market equilibrium, and stable preferences, used relentlessly and unflinchingly." However, the maximizing behavior is not used "relentlessly and unflinchingly” in Walras (Jaffé 1954:165). In this sense, Walras cannot be classified a neoclassical in Becker's sense. 
Following Hahn's definition of the neoclassical school, Kornai was a heterodox, but one who was fascinated by "orthodoxy", particularly by its formal reasoning and its equilibrium paradigm. The major tension of Kornai's thought in the early 1970s was between the system paradigm and the equilibrium paradigm. While Anti-Equilibrium was formally against all three principles of the so-called neoclassical school, its research program was largely determined by the equilibrium paradigm.

\section{ECONOMICS OF SHORTAGE: FROM DISEQUILIBRIUM TO MARSHALLIAN EQUILIBRIUM}

Contrarily to Anti-Equilibrium which was subtitled "On economic systems theory”, Economics of Shortage (1980) was not about economic systems theory, but about a specific state of disequilibrium, namely shortage or suction. The book was principally presented in the field of microeconomics and to a lesser extent in the domain of macroeconomics. But there is no allusion to a third branch of economic systems theory. "The book approaches several questions from the macroeconomic viewpoint. ... Yet the larger part of the book is of microeconomic character. Its main task is to clarify the micro-foundations of macro-processes" (Kornai 1980: 14).

More importantly, while in Anti-Equilibrium, shortage and surplus were characterized as two states of disequilibrium, in Economics of Shortage, both states were regarded as two states of equilibrium. This new way of characterization was related to a distinction between a broad and a narrow sense of equilibrium. The narrow sense of the term was limited to Walrasian equilibrium and the broader was defined as "that state of a system to which it always returns on account of its own regularities” (Kornai 1980: 144). In this sense, shortage and surplus were viewed as non-Walrasian equilibria or the normal state of different economic systems. The term "normal path" of a system was defined as a tendency towards a stable equilibrium (Kornai 1983a: 149, 152, and 156). As demonstrated elsewhere (Vahabi 1998), the normal state is a Marshallian concept of equilibrium that does not exclude market disequilibrium of low intensity. Instead of disequilibrium, Kornai was now reinterpreting any constant deviation from the Walrasian equilibrium as a Marshallian equilibrium. This reinterpretation of disequilibrium as a form of Marshallian equilibrium was in line with various trends of the disequilibrium school advocated by many economists in the 1970s and the 1980s, including Clower, Leijonhufvud, Barro, Grossman, Malinvaud, Grandmont, Benassy, Drèze, Laffont, Laroque, Portes, Younès, and many others (see Vahabi 1993, 2001; De Vroey 2009; Andreff 2016). All these trends were 
inspired by the (neo-)Keynesian and the neoclassical synthesis trying to construct a general equilibrium model based on the interdependence of different markets in partial equilibrium.

In light of this new turn in Kornai's adherence to the equilibrium paradigm, Economics of Shortage provided a self-criticism: "I must acknowledge that my book, Anti-Equilibrium, was itself insufficiently precise in its interpretation of the word "equilibrium". ... I referred to pressure and suction as states of permanent disequilibrium, which suggest that the 'genuine' equilibrium is the Walrasian one. Now..., I consider pressure as well as suction to be normal states of an economy, under suitable conditions” (Kornai 1980: 147). But once non-Walrasian equilibrium is acknowledged, GET cannot be rejected as a benchmark for competitive markets.

Indeed, Kornai revised his position in Economics of Shortage and conceded that GET must be admitted as a normative model or an abstract frame of reference: "Reality is never so 'perfect'". Yet this pure theoretical structure, owing exactly to its 'perfection', seems to be suitable to serve as an abstract frame of reference. The Walrasian system and its specific form: the Walrasian market equilibrium may play a role similar to that of the absolute zero point in physics. Every real physical body has a temperature higher than the absolute zero which cannot be reached by any real cooling. This absolute zero - existing only abstractly but well defined theoretically - may serve as an adequate starting-point of a measurement scale. ... We can elucidate the essential features of an economic system by observing and measuring to what extent it deviates from Walrasian point of reference” (Kornai 1979a: 196-197).

The acceptance of GET as a benchmark of economic efficiency in a competitive market is so important for Kornai (1980) that he distinguishes a socialist system from a capitalist economy with regard to the validity or invalidity of Walras' Law. ${ }^{9}$ At a microeconomic level, Kornai describes the behavior of an enterprise in a perfect competitive market economy to be completely sensitive to price fluctuations since the entrepreneur is subject to hard budget constraint (HBC), ${ }^{10}$ i.e., his expected expenditures cannot exceed its expected revenues, otherwise the enterprise will go bankrupt. Hard budget constraint in Kornai is synonymous with what Clower (1965) calls Say's Principle. Kornai (1979b, 1980) initially forged the concept of soft budget constraint (SBC) to capture the behavior of a socialist enterprise that may survive even in case of persistent losses thanks to the financial

See notes 11 and 13 for Walras' Law and Say’s Principle.

Standard microeconomics does not distinguish soft from hard budget constraint. Budget constraint is by definition hard since the amount of (expected) expenditures cannot exceed (expected) total revenue. 
aid of a paternalistic state. Under such circumstances, the firm becomes nonresponsive to price fluctuations. The concept does not refer to a single bailout, but a recurrent practice of rescuing insolvent firms. Then, managers would expect a rescue if losses are made, and their expectations would shape their behavior. According to Kornai, the SBC is a source of both real and nominal (or monetary) inefficiencies. The first type of inefficiency (real inefficiency) is related to the fact that the presence of ex post bailouts increases the firm's demand for inputs beyond the standard perfectly competitive level and is partially responsible for generating the chronic shortage characteristic of the socialist system. The second type of inefficiency (nominal inefficiency) or the loss in terms of actual distorted prices is related to the fact that firms under the classical socialist system have weak price responsiveness. The SBC reflects the passive role of money in socialist sectors.

Both types of inefficiencies were prevalent in socialist economies because state enterprises were not restrained by their budget constraint or Say's Principle. However, households were subject to the HBC (Kornai 1980: 514) since they could not expect to cover their planned expenditures by anything except their expected revenues. The socialist state had a budget constraint which was neither completely hard, nor completely soft. It was not hard since the state budget had to cover losses of socialist enterprises. It was not always soft since current expenditures of state agencies were usually subject to HBC (Kornai 1980: 528-529). Generally speaking, "In the capitalist system the firm has a hard budget constraint ... in a socialist economy in contrast the firm's budget constraint is soft. ... It follows from this that in the former system Walras's law prevails. In the latter system, however, Walras's law is not effective, at least within the firm sector" (Kornai 1980: 558).

In Economics of Shortage, GET provides a benchmark for measuring the real and nominal inefficiencies of socialist economies in which Walras' Law is not effective. As I have argued in several papers (see for example, Vahabi 2001, 2005, 2014), this type of comparative studies of economic systems has two major shortcomings.

First, Kornai claims that in a perfect competitive market economy, Walras' Law holds since budget constraint (Say's Principle) is valid. However, as Clower - Leijonhufvud (1981) demonstrate, the validity of Say's Principle does not exclude unemployment and thus does not automatically imply the validity of Walras' Law even in a competitive market economy. Although Kornai concedes the distinction made by Clower (1965) between Say's Principle and Walras' Law in the case of a socialist economy, he blurs this distinction with regard to a competitive market economy. In my opinion, the demarcation line between a competitive and a socialist economy cannot be made by referring to the validity of Walras' Law in the former and its non-validity in the latter (Vahabi 2001). 
Second, two contradictory lines of comparative analysis may be distinguished in Kornai's arguments. A first line of comparative analysis consists of comparing genuine socialist economies marked by soft budget constraints (SBC) with an ideal pure competitive economy as a reference point of hard budget constraint (HBC). By contrast, a second line of study advocates a comparison of genuine socialist economies (shortage economies) with genuine capitalist economies (underemployment economies). In Anti-Equilibrium, the comparison was between shortage and surplus economies, while in Economics of Shortage, shortage economy is compared with an ideal competitive market. A comparison of these two works shows that several elements of mainstream economics had been integrated into Kornai's theoretical framework by the end of the 1970s. Kornai prolonged his orientation towards the equilibrium paradigm. Instead of economic systems theory, Kornai was now advocating a microeconomic orientation to develop a Marshallian equilibrium theory of shortages in the market.

However, he introduced an original heterodox idea in the field of microeconomics, namely the soft budget constraint. The concept of budget constraint is one of the fundamental concepts of standard microeconomics ${ }^{11}$ concerning the household's (and not the firm's) behavior. Disregarding the possibility of credit, it simply asserts that the household's total spending plan cannot exceed its budget constraint, namely the total expected monetary revenue at its disposal. Kornai extended the concept of budget constraint to the firm's behavior.

For a long time, the budget constraint has been considered a book-keeping identity (Lange 1942; Samuelson 1948). Budget constraint was first treated as a rational postulate of a household's planned (intended) behavior by Clower (1965)

11 Walras intimated the rationality version of the budget constraint. He imposed a restriction of zero value of (planned) trade for the individual trader, but this was quid pro quo (Say's Principle), not income constrained utility maximization (see Jaffé 1954: 165). According to Jaffé, Walras considered his equations of exchange that were budget constraints as part of the requirements for justice in exchange. This interpretation has been contested by Walker (1996: 47-48) who denied any normative implication for budget constraints in Walras. While the budget constraint is implicitly present in Walras, as Costa (1998: 137) rightly argues, the concept of budget constraint cannot be found in Walras. Allegedly Pareto (1909) first formulated the concept. Hicks acknowledged primarily Pareto - Slutsky (1915), and all later users of the budget constraint concept apparently drew from the same source (see, for example, Kornai 1980). The budget equation in Hicks (1939: 305) bears a close resemblance to Pareto's “budget of the individual” (1909/1927: 160; 1911/ 1955: 90) and Costa (1998: 137) conjectures that constrained utility maximization entered standard price theory by way of Pareto. The modern versions of the concept were first developed by Hicks (1939) and Samuelson (1948); it was then introduced by Arrow - Debreu (1954), Debreu (1959), and Arrow - Hahn (1971) in general equilibrium theory. Patinkin (1956) integrated it into his monetary theory of general equilibrium. 
and Clower - Leijonhufvud (1981). ${ }^{12}$ Clower (1965) applied Say’s Principle (SP) as synonymous with budget constraint and tried to clarify the prevalent confusion among economists between SP and Walras' Law. ${ }^{13}$

According to Clower - Leijonhufvud (1981: 80), Say's Principle (SP) only states that "the net value of an individual's planned trades is identically zero". They intentionally did not refer to the net market value because SP only states that a household's expected or planned purchases cannot exceed its expected or planned revenues. Trades considered by Clower to be "theoretically admissible" are not actual market trades. In this respect, prices and quantities are also included in the context of "mental experimentation" and refer to expected purchase prices and planned quantities and not to quantities actually purchased or prices actually paid (Clower - Due 1972: 64).

Kornai redefined budget constraint (BC) as an empirical fact instead of a rational postulate. While the distinction between hard and soft budget constraints is meaningless in standard microeconomics (Kornai 1979b: 806), it describes two different behavioral regularities in Kornai's theoretical construction. Kornai's HBC amounts to what standard microeconomics consider to be a budget constraint. But this is only empirically held under a "pure" competitive capitalist economy. Conversely, BC is soft under a socialist system where "socialist firms are bailed out persistently by state agencies when revenues do not cover costs" (Kornai 1998: 12).

This distinction at the microeconomic level suffers from a fundamental shortcoming. While the application of the standard microeconomic budget constraint (or Kornai's HBC) does not require any transfer between individual economic units, the SBC implies macroeconomic income redistribution. This makes it difficult to understand why Kornai classifies his concept only within micro theory

12 In these articles, Clower - Leijonhufvud (1981) demonstrate that neoclassical price theory may be regarded as a special case of Keynesian economics, and is valid only under conditions of full employment.

13 Say's Principle or Say's Law is an old subject of controversy among economists. Schumpeter (1954, Vol. 3, Chap. 6) and Sowell (1972) summarized Say's Law in six propositions. Baumol (1977) quoted Say at length, arguing that at least eight different laws or formulations can be derived from Say's works. Lange (1942: 64) argued that application of Say’s Law to a barter economy is a particular case of Walras' Law that applies to a money economy. This argument has been criticized by Clower - Leijonhufvud (1981: 97-98). Finally, Wood - Kates (2000) published five edited volumes regarding different critical assessments of Say's Principle by specialist economists; these are invaluable references. Here, what really matters is not the historical clarification between different versions of Say's Principle or Say's Law, but whether Say's Principle (as an equivalent of budget constraint) describes a book-keeping identity or a rational postulate of an individual transactor's behavior. In this perspective, the distinction between Walras' Law and Say's Principle becomes crucial. 
(Vahabi 2014). Nevertheless, the treatment of BC as an empirical fact is an entirely heterodox original concept that is in conflict with both notions of budget constraint in standard microeconomics, i.e., budget constraint as a book-keeping identity and budget constraint as a rational postulate. Kornai (1979b, 1980) explains this empirical fact by institutional conditions. The adoption of an institutionalist approach is another major heterodox turn in Kornai's thought since the end of the 1970s.

Kornai (1979b: 817) explains this new orientation in an ambiguous way: "The explanatory factors that I considered the main cause of suction in Anti-Equilibrium stayed a role also in the present analysis, but only secondarily. 'Weighting' of the causes has been rearranged. I consider now the main cause of suction the institutional background, concretely: softness, of the budget constraint.” But softness of BC is a behavioral regularity, and it seems here that Kornai is interpreting "behavioralism" as institutionalism. In fact, Kornai (1980) defines soft budget constraint as an economic and not as an institutional phenomenon. ${ }^{14}$ He removes this ambiguity in Kornai (1980: 556): "Ever since I have been doing economic research, the interdependence of the following three groups of phenomena has always interested me: (a) chronic shortage; (b) economic policy improving a fast rate of growth by every means; and (c) certain institutional relations: a high degree of centralization, multilevel control, administrative rationing, and the subordinate role of money and prices. How do these react? Which is the cause and which the effect? Or, to put it less sharply: which elements in the system have a primary role and which only a secondary role? In two of my earlier works, Anti-Equilibrium and Rush versus Harmonic Growth, I regarded phenomenon (a) and (b) as primary. Many were opposed to this view, emphasizing that it is the group of phenomena in (c) that plays a primary causal role. It appears from my present book that I am now inclined to accept this view. The main explanation of chronic shortage lies in the institutional conditions, and the behavioral rules they lead to.” Kornai is referring to the Hungarian institutionalist economists, particularly Tamás Bauer's (1973) critique of Anti-Equilibrium for the lack of an institutionalist perspective.

Institutional relations are now clearly related to paternalism or bureaucratic coordination mechanism (other forms of coordination such as market, ethical, or

14 Kornai (1980: 569) avers: “There is a close relationship between the set of economic phenomena in the strict sense (the soft budget constraint, almost-insatiable demand, horizontal and vertical 'pumping') and the set of institutional phenomena (the higher degrees of paternalism): the latter set largely explains the former one.” Kornai clearly maintains that behavioral regularity is decided by institutional conditions: "The book has throughout reflected the view that definite social relations and institutional conditions generate definite forms of behavior, economic regularities and norms” (ibid.: 569). 
aggressive) that were defined later in Kornai (1984). ${ }^{15}$ However, power and property relationships are not yet mentioned. This partial institutionalism is in line with what Kornai called the "soul" of systems theory in Anti-Equilibrium.

Summing up Kornai's position on GET in this second phase, we find him again half-in, half-out of the mainstream. Although he becomes more "neoclassical" by redefining disequilibrium in terms of Marshallian equilibrium and by adopting a microeconomic orientation in explaining macroeconomic aggregates, his insistence on an empirically based microeconomics, his soft budget constraint, and institutionalist approach reflect his heterodox position. While the system paradigm is only tangentially treated in Kornai (1980), the new institutionalist orientation influences Kornai's pursuit for systems economic theory from a methodological perspective.

\section{BY FORCE OF THOUGHT: FROM MARSHALLIAN TO WALRASIAN EQUILIBRIUM}

Kornai's autobiography is the coup de grâce for the main message of Anti-Equilibrium: "I began the section by pointing to an essential mistake in the domain of the philosophy of science in Anti-Equilibrium. I should have attacked not the purity of the theory (the abstract, unreal nature of its assumptions), but the wrong use of it in mainstream economics. The real addressee of the critique should have been mainstream teaching practices and research programs" (Kornai 2006: 184-185). There is no trace of disequilibrium or normal state in this self-critical appraisal. The distinction between Walrasian and non-Walrasian equilibrium is equally disregarded since Kornai has now come to accept GET as a normative model. Accordingly, he accepts Frank Hahn's criticism and call for reforms and abandons his project to revolutionize GET: "Looking back today, I consider that revolutionary approach to have been mistaken. ... When writing Anti-Equilibrium, I undervalued the willingness and ability of mainstream economics to renew itself" (ibid.: 192). Here we find a third phase in Kornai's thought on equilibrium, in which Kornai goes beyond the defense of equilibrium in a broad sense (i.e., what he calls normal state or Marshallian equilibrium) and becomes an advocate of equilibrium in its narrow or Walrasian sense. He now claims that GET, in its purity, provides an abstract reference for market efficiency. The problem is rather

15 Other forms of coordination such as market, ethical or aggressive have been defined later in Kornai (1984). Kornai's description of institutions or coordination mechanism is inspired by Karl Polanyi's social forms of integration, namely exchange, redistribution, and reciprocity (see Vahabi 2009). 
the way GET has been taught and the manner in which research projects have been tailored.

Kornai also revises his position with regard to the rationality postulate: "Given the line of argument just expressed, the extreme model that assumes a rigorously consistent decision maker can do useful service. It can serve as a standard for establishing what inconsistencies are apparent in a real decision maker's behavior - in what decisions, in what direction, to what degree, and with what frequency it departs from that of an ideally consistent decision maker. It is regrettable that Anti-Equilibrium did not appreciate that valuable role sufficiently” (ibid.: 185). Kornai is no more against the use of maximizing assumption in describing human behavior on economic issues; he completely disregards Simon's "saticficing” criterion employed in some of his co-authored formal models (Kornai Weibull 1983b).

Borrowing again Hahn's definition of the neoclassical school, Kornai (2006) might be classified as a neoclassical economist since he adheres to all three elements of Hahn's thought, namely microeconomic orientation, rationality postulate, and equilibrium (both Marshallian and Walrasian). In this sense, he goes with the stream, but the mainstream of neoclassical synthesis does not play an influential role in the era of the New Classical School (Rational Expectations and Real Business Cycles, see Snowdon - Vane 2005; de Vroey 2016). The new mainstream of rational expectations and economic imperialism marks the end of the neoclassical synthesis. According to the New Classical School, Walrasian general equilibrium is not only a normative model of competitive markets, but also a description of the way markets function in reality. All forms of disequilibrium are assumed to be a reflection of an intertemporal adaptation to external shocks rather than lack of coordination among decentralized agents. Kornai's critical stand towards mainstream teaching practices and research programs addresses this new mainstream: "Among the readers of the Hungarian edition of this book, I found some who thought that my criticism here of the mainstream in teaching and research applied far more to the present state of affairs, the period after the theories related to 'rational expectations' became very influential, than to that of thirty-five years ago, when I was writing Anti-Equilibrium. Thus in a way, Anti-Equilibrium received later recognition for pointing ahead to likely problems” (Kornai 2006: 185). In other words, although Anti-Equilibrium was not a valid criticism of GET, it correctly predicted and provided an appropriate critique of today's mainstream economics.

Again on rational choice theory, Kornai (ibid,: 186) implicitly criticizes the Chicago School of economics because of its non-subtle use of the model in explaining all non-economic human behavior: "Exponents claim to have a universal explanatory model of human behavior on their hands, able to describe anything 
- not just narrowly economic decisions but all problems of choice, from divorce and family size up to parliamentary votes." Rejecting the extension of economic assumption of rational-choice behavior to all other fields of social sciences, Kornai underlines: "The rational choice model has begun to be widely employed in sociology and political science, and even in history ... Unfortunately, in these disciplines the theory of rational choice is not used in the subtle way suggested above. Because its interpretations are often quite crude and oversimplified, the warnings and criticism of several decades ago have not lost their immediacy" (ibid.: 188). There is a problem with Kornai's critique of extending rationality assumption to other fields of social science. Kornai was one of the first protagonists and users of Game theory. This "qualitative mathematics" (Lévi-Strauss 1954: 647-648; Braudel 1958: 746) was applied to different fields of the human and social sciences, notably in linguistics, communication, theoretical biology, politics, anthropology, military science, economics, sociology, and even in literature and critical analysis of evangelical texts. Game theory has been extensively used as a common tool in different disciplines on the basis of rational players. Formal reasoning, particularly game theory, was one of the major sources of resorting to the rationality assumption in an interdisciplinary perspective. Given Kornai's interest in game theory and his constant collaboration with game theorists, including Maskin and Roland, it would have been useful if Kornai could clarify whether he is against the adoption of the rationality assumption in game theory applied in other fields of social sciences. Unfortunately, Kornai leaves this question unanswered.

In sum, according to Kornai (2006), he is a neoclassical, but not a New Classical. However, there are two problems for which we do not find any clue in Kornai (2006). The first one is economic systems theory and the second one is the soft budget constraint.

As noted earlier, the sub-title of Anti-Equilibrium is On Economic Systems Theory and the Tasks of Research. GET was presented as part of a new branch of economics devoted to economic systems theory. Kornai (1980) adopted an institutionalist approach in analyzing economic relationships. The Socialist System (1992) and Kornai's other writings on the post-socialist transition are focused on the system paradigm within an institutional perspective. What is the place of GET within an institutionalist perspective of the system paradigm?

A second problem is related to the notion of the soft budget constraint as an empirical fact. How can soft budget constraint as an empirical fact be reconciled with GET? 


\section{KORNAI AND NEW MICROECONOMICS}

Soft budget constraint (SBC) is irreconcilable with standard microeconomics since rational agents would never violate their budget constraints as either a book-keeping identity or a rational planning postulate (Say’s Principle). Contrary to standard microeconomics, new microeconomics is based on the strategic behavior of agents interacting with other agents. The SBC can be integrated in new microeconomics as a more general dynamic commitment problem in which an agent can fail to take an efficient action, or can undertake an inefficient action because he knows that he will receive additional financing. Dewatripont Maskin (1995) pioneered this endogenous explanation of SBC. They argued that the SBC syndrome occurs whenever a funding source (e.g., a bank or government) finds it impossible to keep an enterprise to a fiscal budget (i.e., whenever the enterprise can extract a bigger subsidy ex post or loan more than would have been considered efficient ex ante). In this sense, the SBC problem is not specific to socialist economies because the extent to which loss-making firms or projects are terminated or refinanced is also very relevant in capitalist (both developed or undeveloped) economies. In short, the time inconsistency of the Centre lies at the heart of the SBC syndrome: if the Centre were able to credibly commit not to subsidize a firm ex post, the firm would make more efficient ex ante decisions. Hardening of the budget constraint then means creating conditions for a credible commitment not to refinance an agent.

Since the pioneering work of Dewatripont - Maskin (1995), an abundant body of formal literature has explained the SBC endogenously through adverse selection, moral hazard, and rent-seeking (for detailed surveys, see Maskin 1996; Kornai et al. 2003; Vahabi 2001, 2005, 2014). The SBC is thus integrated into the new microeconomics as a special case of time inconsistency. Nonetheless, these endogenous versions of the SBC and Kornai's exogenous version of the SBC as the ex post bailouts of loser firms by a paternalistic state still differ fundamentally. To clarify the difference, we can simply ask what would happen if, ex ante, the creditor knows with certainty that the firm will be a loss-maker.

In all endogenous models of the SBC, "if a creditor learns ex ante that the firm is definitely a 'bad' firm, it will refuse to finance it since to do so would be throwing money away. This is in sharp contrast to a model of ex post bailouts due to paternalism because in such a model the likelihood of obtaining financing is unaffected by ex ante revelation to the creditors that the firm is expected to be loss-making. If the firm is loss-making ex post, it is subsidized as a result of its situation and, consequently, the firm has a soft budget constraint" (Schaffer 1998: 84). In other words, Kornai and Maskin are not talking about the same thing. 
While Maskin's endogenous SBC fits within profit-maximizing behavior and is consistent with the new microeconomics, Kornai's theory of the SBC is inconsistent with profit-maximizing behavior. "In describing the behavior of the firm, we want to have a more general framework than the usual profit-maximizing pattern ... In addition, we apply - following Simon (1959) - the satisfying model of decision-making. This approach seems to be more general and realistic, and in the present model profit maximizing appears as a special case of the more general pattern" (Kornai - Weibull 1983b: 166).

For Maskin, soft budget constraint is the outcome of a choice related to strategic behavior of a maximizing agent in the absence of credible commitments. By contrast, for Kornai, soft budget constraint is an empirical fact generated by institutional constraints. The theoretical synthesis between formal and institutional explanations of the soft budget constraint as suggested by Kornai et al. (2003) is theoretically incoherent since the concept of soft budget constraint is not the same in exogenous and endogenous explanations (Vahabi 2014). A half-in, half-out of mainstream synthesis is rather a source of confusion obfuscating the heterodox message of Kornai's original concept of SBC.

\section{CONCLUSION}

Undoubtedly, Kornai is one of the eminent economists of the $21^{\text {th }}$ century who demystified the socialist economy as a shortage economy. Bridging the Eastern and Western economists with regard to GET is only one of his contributions. More importantly, he is one of the pioneers of system paradigm, and the inceptor of the concept of soft budget constraint that has been a major source of theoretical inspiration and policy-making implications for many international organizations (such as the IMF and the World Bank) during the post-socialist transition. His ideas on investment hunger, the soft budget constraint, and state paternalism influenced the Chinese economic reform since the Bashan Conference in 1985 (Gewirtz 2017). It is not by chance that he could publish in all leading economic journals, orthodox or heterodox. It is surprising that the Nobel Prize has never been granted to a scholar whose name is closely associated with the intellectual preparation of the most important economic transition of the post-cold war period, namely the post-socialist transition.

Reviewing the chapter on Anti-Equilibrium in his auto-biography reveals some of the reasons behind this enigma: "I certainly caused several difficulties in my later career by writing and publishing Anti-Equilibrium. It was seen as unforgivable by some diehard, blinkered members of the neoclassical school" (Kornai 2006: 195). In Kornai's self-critical appraisal, his misleading critique of 
GET was only one part of the story, but mainstream economics should also bear another part of the responsibility because it treated Kornai's errors as unforgivable blasphemy: "In this chapter - as in other parts of the book - I have striven for honest introspection. I have tried to find out how much responsibility I bore for Anti-Equilibrium's not achieving the effect I had expected it would. Among other things, this honesty gives me the moral basis to ask, 'Can the lack of success be attributed only to me?' It is not ill-feeling that makes me seek an answer to this question. I am speaking for many researchers when I broach the issues of the profession's refusal to accept heavy criticism and of its shortness of memory; that memory ought to honor the first appearance of important - primitive, clumsy, but nevertheless pioneering - new ideas” (ibid.: 197). The dogmatic and sectarian spirit of mainstream economics is a whole chapter that warrants a thorough study of the sociological and theoretical evolution of economists as a caste (Schumpeter 1954) and of the economic profession as institutionalized knowledge. In this concluding part, I would like to return to the cause of Kornai's so-called failure. Kornai's intellectual honesty is exemplary; he always reexamines his earlier positions and if he finds them wrong, he explicitly acknowledges them. It needs a lot of theoretical courage and personal integrity to admit that Hahn (1973) was right in his critique of Anti-Equilibrium. No-one could describe better than Kornai himself his relationship with mainstream economics: "On some questions I go with the stream, and in other cases I try to swim up the stream. This half-in, halfout situation sometimes causes conflicts” (Kornai 2006: 195). Is there any relationship between Kornai's half-in, half-out situation and his so-called failure?

It is true that although Kornai's Anti-Equilibrium was very close to post-Keynesian economics, he did not treat "equilibrium economics as irrelevant” (Kaldor 1972). He tried to bring together economic systems theory with equilibrium economics, and the outcome of this half-in, half-out position was nothing but a "failure”. Kornai started with disequilibrium, then accepted Marshallian equilibrium, and finally ended up with Walrasian general equilibrium. In fact, this long journey was related to his initial choice of taking equilibrium economics as relevant, although he never showed the relationship between GET and economic systems theory. Did Kornai need to entertain such a half-in position with GET to develop his theory of soft budget constraints? The same question can be raised again when he lends credence to a synthesis of formal and institutional theories of the SBC.

Kornai's work is colossal and whatever his tactical choice in introducing his ideas, both orthodoxy and heterodoxy would need him to enrich the way they understand the economic world. 


\section{REFERENCES}

Andreff, W. (2016) : Edmond Malinvaud et la planification décentralisée. Colloque Théorie, mesure et expertise: Edmond Malinvaud et les reconfigurations de la théorie économique, 1950-2000. Paris, Maison des Sciences Economiques, 8-10 décembre 2016.

Arrow, K. J. (1974): General Economic Equilibrium: Purpose, Analytic Techniques, Collective Choice. The American Economic Review, 64(3): 253-272.

Arrow, K. J. - Debreu, G. (1954): Existence of an Equilibrium for a Competitive Economy. Econometrica, 22(3): 265-290.

Arrow, K. J. - Hahn, F. (1971): General Competitive Analysis. San Francisco: Holden-Day.

Baumol, W. (1977): Say's (at Least) Eight Laws, or What Say and James Mill May Really Have Meant? Economica, 44: 65-80.

Bauer, T. (1973): Kornai, Janos: Anti-Equilibrium. On Economic Systems Theory and the Task of Research. Book Review. Magyar Tudomány, 18: 129-132. (in Hungarian).

Becker, G. S. (1976): The Economic Approach to Human Behavior. Chicago: University of Chicago Press.

Braudel, F. (1958) : Histoire et sciences sociales: La longue durée. Annales, Histoire, Sciences Sociales, 13(4): 725-753.

Clower, R. (1965): The Keynesian Counterrevolution: A Theoretical Appraisal. In: Hahn, F. H. Brechling, P.P.R. (eds): The Theory of Interest Rates. London: Macmillan, Chapter 5.

Clower, R. - Due, J. (1972): Microeconomics. Homewood, Illinois: Richard D. Erwin (Sixth edition).

Clower, R. - Leijonhufvud, A. (1981): Say’s Principle, What It Means and Doesn’t Mean. In: Leijonhufvud, A. (ed.): Information and Coordination. Oxford: Oxford University Press.

Cohen, A. J. - Harcourt, G. C. (2003): Whatever Happened to the Cambridge Capital Theory Controversies? Journal of Economic Perspectives, 17(1): 199-214.

Costa, M. L. (1998): General Equilibrium Analysis and the Theory of Markets. Cheltenham, UK Northampton, MA, USA: Edward Elgar.

Debreu, G. (1959): Theory of Value: An Axiomatic Analysis of Economic Equilibrium. New York: John Wiley and Sons.

De Vroey, M. (2009): A Marshall - Walras Divide? A Critical Review of the Prevailing Viewpoints. History of Political Economy, 41(4): 709-736.

De Vroey, M. (2016): A History of Macroeconomics, from Keynes to Lucas and Beyond. New York: Cambridge University Press.

Dewatripont, M. - Maskin, E. (1995): Credit and Efficiency in Centralized and Decentralized Economics. Review of Economic Studies, 62(4): 541-555.

Gewirtz, J. (2017): Unlikely Partners, Chinese Reformers, Western Economists, and the Making of Global China. Cambridge Mass.: Harvard University Press.

Hahn, F. (1973): The Winter of Our Discontent. Economica, New Series, 40(159): 322-330.

Hahn, F. (1984): Equilibrium and Macroeconomics. Oxford: Basil Blackwell.

Hicks, J. (1939): Value and Capital. New York: Oxford University Press.

Jaffé, W. (1954): Elements of Pure Economics. London: George Allen and Unwin.

Kaldor, N. (1972): The Irrelevance of Equilibrium Economics. Economic Journal, 82(328): 12371255.

Kornai, J. (1971a): Anti-Equilibrium. On Economic Systems Theory and the Tasks of Research. Amsterdam, Oxford, North-Holland, New York, American Elsevier Publishing Company, Inc.

Kornai, J. (1971b): Economic Systems Theory and General Equilibrium Theory. Acta Oeconomica, 6(4): 297-317. 
Kornai, J. (1971c): Pressure and Suction on the Market. International Development Research Center, Indiana University, Bloomington, Indiana, No. 47401.

Kornai, J. (1972): Rush versus Harmonic Growth. Meditation on the Theory and on the Policies of Economic Growth. Amsterdam: North-Holland.

Kornai, J. (1979a): Economists and Economic Thought: The Oeuvre of Kenneth J. Arrow. Acta Oeconomica, 23(1/2): 193-203.

Kornai, J. (1979b): Resource-Constrained versus Demand-Constrained Systems. Econometrica, 47(4): 801-819.

Kornai, J. (1980): Economics of Shortage. Amsterdam: North-Holland.

Kornai, J. (1983a): Equilibrium as a Category of Economics. Acta Oeconomica, 30(2): 145-159.

Kornai, J. (1983b): The Health of Nations: Reflections on the Analogy between the Medical Sciences and Economics. Kyklos, 36(2): 191-212.

Kornai, J. (1984): Bureaucratic and Market Coordination. Osteuropa Wirtschaft, 29(4): 306-319.

Kornai, J. (1992): The Socialist System. The Political Economy of Communism. Princeton University Press, Oxford University Press.

Kornai, J. 1(998a): The Place of the Soft Budget Constraint in Economic Theory. Journal of Comparative Economics, 26(1): 11-17.

Kornai, J. (2006): By Force of Thought, Irregular Memoirs of an Intellectual Journey. Cambridge, Mass., London: MIT Press.

Kornai, J. (2016): The System Paradigm Revisited, Clarification and Additions in the Light of Experiences in the Post-Socialist Region. Acta Oeconomica, 66(4): 547-596.

Kornai, J. - Dániel, Zs. (1986): The Chinese Economic Reform - As Seen by Hungarian Economists (Marginal Notes to Our Travel Diary). Acta Oeconomica, 36(3/4): 77-89.

Kornai, J. - Maskin, E. - Roland, G. (2003): Understanding the Soft Budget Constraint. Journal of Economic Literature, 44(4): 1095-1136.

Kornai, J. - Weibull, J. W. (1983b): Paternalism, Buyers' and Sellers' Market. Mathematical Social Sciences, 6(2): 153-169.

Kovács, J. M. (1991): From Reformation to Transformation Limits to Liberalism in Hungarian Economic Thought. East European Politics and Societies, 5(1): 41-72.

Lange, O. (1942): The Foundations of Welfare Economics. Econometrica, 10(3/4): 215-228.

Leijonhufvud, A. (1968): On Keynesian Economics and the Economics of Keynes: A Study of Monetary Theory. New York: Oxford University Press.

Lévi-Strauss, C. (1964) : Les mathématiques de l'homme. Bulletin International des Sciences Sociales, 6(4) : 643-653.

Mihalyi, P. (2017): Kaldor and Kornai on Economics without Equilibrium - Two Life Courses. Acta Oeconomica, 67(Special Issue): 47-66.

Neuberger, E. - Duffy, W. (1976): Comparative Economic Systems, a Decision-Making Approach. Boston: Allyn \& Bacon, Inc.

Pareto, V. (1909/1927/1971): Manual of Political Economy. New York: Kelley.

Pareto, V. (1911/1955): Mathematical Economics. International Economic Papers, 5: 58-102; translated from Encyclopédie des Sciences Mathématiques, vol. I (iv, 4), Paris, Teubner, Gauthier, Villars.

Patinkin, D. (1956): Money, Interest and Prices; An Integration of Monetary and Value Theory. Evanston, Ill., Row, Peterson.

Samuelson, P. (1948): Economics, an Introductory Analysis. N.Y.: McGraw-Hill Co.

Schaffer, M. (1998): Do Firms in Transition Economies Have Soft Budget Constraint? A Reconsideration of Concepts and Evidence. Journal of Comparative Economics, 26(1): 80-103.

Schumpeter, J. A. (1954): History of Economic Analysis. N.Y.: Oxford University Press. 
Simon, H. (1979): Rational Decision Making in Business Organizations. American Economic Review, 69(4): 493-513.

Snowdon, B. - Vane, H. (2005): Modern Macroeconomics - Its Origins, Development and Current State. Cheltenham: Edward Elgar.

Sowell, T. (1972): Say’s Law. Princeton: Princeton University Press.

Vahabi, M. (1993): La pensée économique de Janos Kornai (1955-1984), de la réforme de l'économie socialiste à la théorie de l'économie de pénurie (Janos Kornai’s Economic Thought (19551984), from Reforming the Socialist Economy to the Economics of Shortage). Ph.D. Dissertation, University of Paris VII, Jussieu-Denis Diderot.

Vahabi, M. (1998): The Relevance of the Marshallian Concept of Normality in Interior and in Inertial Dynamics as Revisited by G. Shackle and J. Kornai. Cambridge Journal of Economics, 22(5): 547-572.

Vahabi, M. (2001): The Soft Budget Constraint: A Theoretical Clarification. Louvain Economic Review, 67(2): 157-195.

Vahabi, M. (2005) : La contrainte budgétaire lâche et la théorie économique. Revue d'Etudes Comparatives Est-Ouest, 36(2): 143-176.

Vahabi, M. (2009): An Introduction to Destructive Coordination. American Journal of Economics and Sociology, 68(2): 353-386.

Vahabi, M. (2014): Soft Budget Constraint Reconsidered. Bulletin of Economic Research, 66(1): $1-19$.

Walker, D. A. (1996): Walras's Market Models. New York: Cambridge University Press.

Walras, L. (1874/1965): Elements of Pure Economics; Or, The Theory of Social Wealth. Translated by W. Jaffé, Homewood, Ill., R. D. Irwin.

Wood, J. C. - Kates, S. (eds) (2000): Jean-Baptiste Say. Critical Assessments of Leading Economists. London and New York: Routledge. 